T. 2, № 1, 2020

УДК 621.311

П. М. Баран

Національний університет “Львівська політехніка”, кафедра електроенергетики та систем управління, e-mail: petro.m.baran@lpnu.ua

В. П. Кідиба

Національний університет “Львівська політехніка”, кафедра електроенергетики та систем управління, e-mail: kidyba@ukr.net

Я. Д. Пришляк

Національний університет “Львівська політехніка”, кафедра електроенергетики та систем управління, e-mail: pryshlak@gmail.com

I. O. Сабадаш

Національний університет “Львівська політехніка", кафедра електроенергетики та систем управління, e-mail: office@imskoe.org.ua

\title{
АВТОМАТИЧНЕ ПОВТОРНЕ ВВІМКНЕННЯ В ЕЛЕКТРИЧНІЙ МЕРЕЖІ 3 ІЗОЛЬОВАНОЮ НЕЙТРАЛЛЮ ЗА ОДНОФАЗНОГО ЗАМИКАННЯ НА ЗЕМЛЮ
}

https://doi.org/10.23939/sepes2020.01.001

(C) Баран П. М., Кідиба В. П., Пришляк Я. Д., Сабадаш I. О., 2020

Електричні мережі 6-35 кВ працюють з ізольованою чи уземленою через дугогасний реактор нейтраллю. Цей режим нейтралі $є$ причиною появи значних перенапруг 3 крутими фронтами хвиль в електричній мережі за однофазних замикань на землю (О33), особливо за дугових замикань та різного роду ферорезонансних явищ. Ці перенапруги пошкоджують ізоляцію всієї електричної мережі. Тому для підвищення ефективності функціонування мережі 6-35 кВ необхідно до мінімуму зменшити час дії згубних для ізоляції мережі (особливо кабелів) перенапруг. Для цього необхідно застосовувати захисти, що діють на вимкнення присднання 3033 із мінімальною витримкою часу. Для зменшення збитків від недовідпуску електроенергії за рахунок зменшення часу знеструмлення споживачів, що вимикалися захистом за О3З, доцільно застосовувати автоматичне повторне ввімкнення (АПВ), що діс на автоматичне увімкнення елемента електричної мережі, попередньо вимкненого захистом за О33.

Розроблено алгоритм функціонування АПВ. На основі розробленого алгоритму 3 застосуванням цифрових технологій виготовлений пристрій, за допомогою якого може бути організована функція АПВ для великої кількості присднань до секції шин - до 28. 
Для перевірки працездатності пристрою створена фізична модель електричної мережі з ізольованою нейтраллю, що дозволяс моделювати ОЗЗ. Для захисту від ОЗЗ у фізичній моделі застосований серійний пристрій «Альтра», що успішно експлуатусться на різних електроенергетичних об'сктах України - обленерго, теплових електричних станціях, заводських підстанціях тощо. Взаємна робота пристроїв захисту від ОЗ3 та АПВ опробувана на фізичній моделі. Моделювались різноманітні режими за ОЗ3 в електричній мережі (пошкодження в різних місцях електричної мережі) та різний характер ОЗ3 (короткочасні 3 самоліквідацісю, стійкі без самоусунення). Аналіз результатів перевірки на фізичній моделі підтвердив високу ефективність комплексного використання пристроїв захисту за О3З та АПВ у мережах з ізольованою (компенсованою) нейтраллю. Зараз пристрій знаходиться в дослідній експлуатації на одній із підстанцій “Львівобленерго”.

Ключові слова: підстанція; релейний захист; автоматика; однофазне замикання на землю; автоматичне повторне ввімкнення; цифровий пристрій; “Альтра”; інформаційна мережа.

\section{Постановка проблеми}

Для зменшення збитків від недовідпуску електроенергії споживачам, що вимикалися захистом за однофазного замикання на землю, пропонується їх вмикати пристроями автоматичного повторного ввімкнення. Це в першу чергу стосується споживачів, приєднаних до шин підстанцій кабелями з паперовою оливопросоченою ізоляцією.

\section{Актуальність дослідження}

Як показав досвід експлуатації, більшість О3З в мережах 3 ізольованою (компенсованою) нейтраллю є дуговими (70-90 \% всіх О33). Навіть стійкі (“металічні”) О3З починаються 3 дугових замикань різної тривалості. Режим дугових О33 є небезпечним для ізоляції всієї електричної мережі через наявність в ній перенапруг з крутими фронтами хвиль. Під час виникнення дугового ОЗ3 також можуть виникати ферорезонансні явища, для яких характерним є значне підвищення фазних напруг мережі, що може спричиняти пробій ізоляції обладнання. За виникнення ферорезонансу насамперед 3 ладу виходять трансформатори напруги (згідно зі статистичними даними за рік виходить 3 ладу до 10 \% від загальної кількості трансформаторів напруги) та можуть пошкоджуватись кабелі електрично зв'язаної мережі [1]. Крім того, такі перенапруги викликають прискорену деградацію (старіння) ізоляції. Тому режими О33, особливо дугові, для електричних мереж 3 ізольованою (компенсованою) нетраллю є небезпечними [2]. Враховуючи вищенаведене, захисти за виникнення О3З у мережах з ізольованою (компенсованою) нейтраллю повинні діяти на вимкнення пошкодженого елемента 3 мінімальною можливою витримкою часу [3].

В електричних мережах з ізольованою (компенсованою) нейтраллю часто виникають О33, що супроводжуються частковими пробоями (короткочасними уземленнями фази). За часткових пробоїв в більшості випадків ізоляція в місці пошкодження самовідновлюється (або відновлюється після зняття напруги). У разі використання швидкодійного релейного захисту, вимкнене ним приєднання, в якому відновилась ізоляція, може вводитись в роботу. Для цього доцільно застосувати автоматичне повторне ввімкнення, що здійснює увімкнення елемента, попередньо вимкненого захистом за О33 в електричній мережі з ізольованою (компенсованою) нейтраллю. Це дозволить зменшити збитки від недовідпуску електроенергії за рахунок зменшення часу знеструмлення споживачів, що вимикалися захистом за О33.

\section{Формулювання мети та завдань статті}

Метою дослідження $€$ розроблення алгоритму функціонування АПВ за однофазного замикання на землю в електричній мережі з ізольованою (компенсованою) нейтраллю, створення цифрового пристрою та перевірка його працездатності. 
Аналіз останніх досліджень і публікацій

Сьогодні для захисту приєднань підстанцій з ізольованою або компенсованою нейтралями за О33 ефективним є застосування цифрових пристроїв “Альтра” [4-6], для яких характерними $€$ висока чутливість та селективність роботи. Принцип роботи пристрою за виникнення О3З на приєднанні базується на аналізі струмів нульової послідовності приєднань до секції шин (СШ) підстанції та напруги нульової послідовності СШ.

\section{Виклад основного матеріалу}

Автоматичне повторне ввімкнення за однофазного замикання на землю (АПВ) призначене для автоматичного увімкнення приєднання, що було вимкнене пристроєм захисту за О33 [7, 8]. Як захист за ОЗ3 використаємо пристрій “Альтра”. Цей пристрій забезпечує комплексний контроль ізоляції кожного приєднання секції шин 6-35 кB, селективно визначає приєднання секції шин після виникнення на ньому О3З та формує сигнал на його вимкнення. Для запуску АПВ обов'язковою $є$ дія пристрою захисту за ОЗ3 на вимкнення пошкодженого приєднання.

Для роботи АПВ необхідно забезпечити виконання таких умов:

- пуск АПВ здійснюється тільки після спрацювання пристрою захисту за О3З;

- після увімкнення вимикача приєднання на визначений час блокується запуск АПВ;

- $\quad$ дія АПВ має бути однократною.

Функціональну схему, що реалізує роботу АПВ, наведено на рис. 1. Схему показано для одного приєднання.

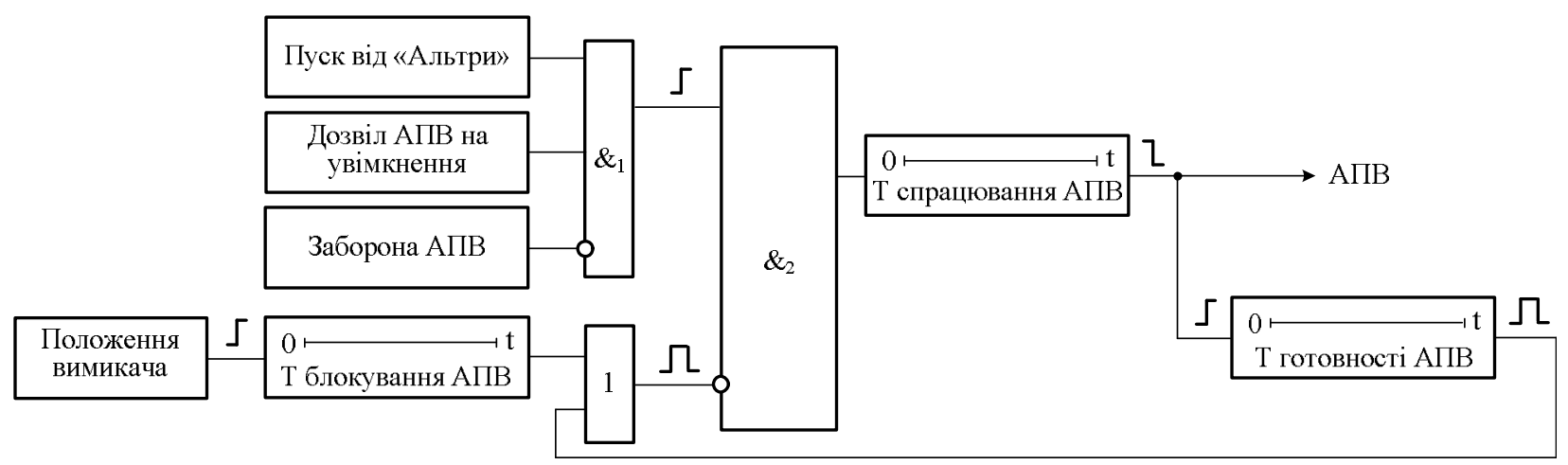

Рис. 1. Функиіональна схема роботи АПВ

Для організації АПВ необхідно контролювати стан вихідних реле пристрою захисту за ОЗ3, які діють на вимкнення вимикачів приєднань та стан вимикачів цих приєднань.

Дозвіл на пуск АПВ формуватиметься (сигнал на виході логічного елемента $\&_{2}$ ) у випадку:

1) наявності сигналу на першому вході логічного елемента $\&_{2}$, який буде після виконання наступних умов:

-пройшло вимкнення приєднання від захисту за О3З (контролюється, як правило, спрацюванням відповідного вихідного реле);

- дозволена дія АПВ на увімкнення (задається в конфігурації пристрою АПВ);

- немає заборони дії АПВ від інших пристроїв РЗА підстанції;

2) відсутності сигналу на інверсному вході логічного елемента $\&_{2}$.

Блокування дії АПВ виконане на інверсному вході логічного елемента $\&_{2}$. Воно здійснюється завдяки наявності сигналу на виході логічного елемента 1 , який утримується протягом часу, що визна-

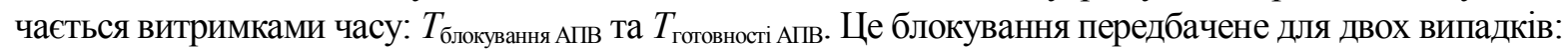

- відразу після увімкнення вимикача (появи сигналу “Положення вимикача"), коли можливе увімкнення на закоротку та спрацювання захисту від міжфазних к.з., який повинен вимикати вимикач 3 мінімальною можливою витримкою часу. В цьому випадку повторне ввімкнення від АПВ не має сенсу; 
- $\quad$ після увімкнення вимикача від АПВ. Тим самим забезпечується однократність дії АПВ. Якщо О3З стійке, то дія АПВ. 3 неуспішна, автоматично вмикати вимикач приєднання другий раз немає потреби.

Після появи сигналу на виході логічного елемента $\&_{2}$ запускається таймер, який відраховує

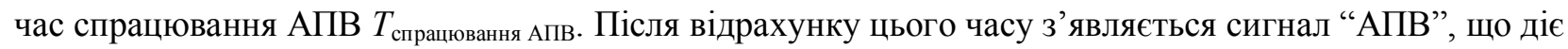
на електромагніт увімкнення вимикача приєднання.

На основі розробленого алгоритму функціонування АПВ в Інституті мікропроцесорних систем керування об'єктами електроенергетики (IМСКОЕ) - виготовлено цифровий термінал “Альтра-АПВ-ОЗ3”. “Альтра-АПВ-ОЗ3” - це сучасний цифровий прилад, що забезпечує автоматичне повторне ввімкнення приєднання системи шин 6-35 кВ після вимкнення його захистом за О33. Один пристрій встановлюють для організації функції АПВ для 28 приєднань включно (у випадку більшої кількості приєднань встановлюють два або більше пристроїв). Для контролю стану вимикачів передбачено $N$ бінарних входів за кількістю контрольованих приєднань захистом за ОЗ3 “Альтра”. Для управління вимикачами приєднань передбачено $N$ бінарних виходів (в терміналі вони реалізовані на електромеханічних проміжних реле).

Як правило пристрій АПВ “Альтра-АПВ-ОЗ3” працює разом з пристроєм захисту за ОЗ3 “Альтра".

Для отримання інформації від пристроїв “Альтра" та “Альтра-АПВ-ОЗ3” організовується інформаційна мережа. Інформаційна мережа управління пристроями АПВ та захисту за ОЗ3 наведена на рис. 2. Доступ до пристроїв “Альтра-АПВ-О33” та “Альтра” організований на основі "Концентратора". Зв'язок "Концентратора" з диспетчером може здійснюватись як по GSM мережі, так і по Ethernet мережі. «Концентратор» містить вбудований комп'ютер, GPS модуль та GSM модем. Він забезпечує збирання інформації від пристроїв, їх часову синхронізацію, передачу інформації на вищий рівень ієрархії управління та можливість зміни їх конфігурації. Зв'язок пристроїв “Альтра-АПВ-ОЗ3” та “Альтра" 3 “Концентратором” здійснений за допомогою двопровідної лінії зв'язку типу “вита пара” з використанням інтерфейсу RS-485.

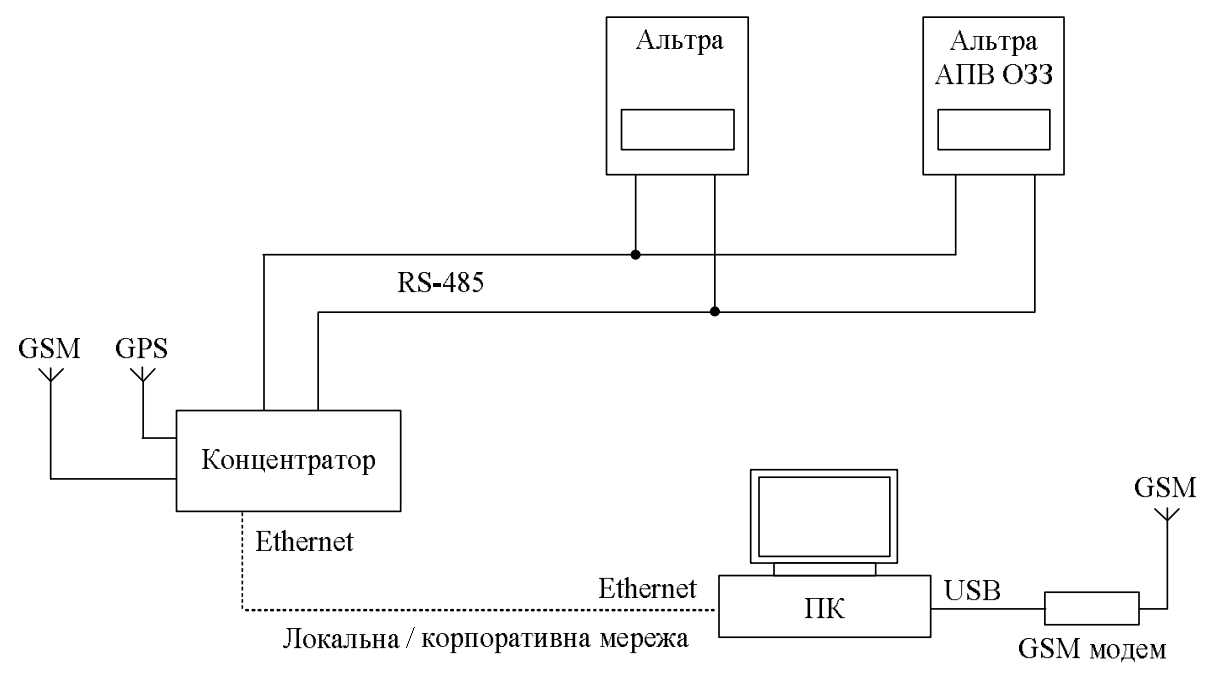

Рис. 2. Інформаційна мережа пристроїв “Альтра-АПВ-ОЗ3” та “Альтра”

Управління пристроями інформаційної мережі здійснюється через ПК диспетчера.

Для перевірки працездатності пристрою на кафедрі електроенергетики та систем управління створено фізичну модель електричної мережі з ізольованою нейтраллю, що дозволяє моделювати О33 $[9,10]$. Ця фізична модель електричної мережі представляє собою характерний фрагмент типової міської електричної мережі. Принципова схема фізичної моделі електричної мережі наведена на рис. 3 . 


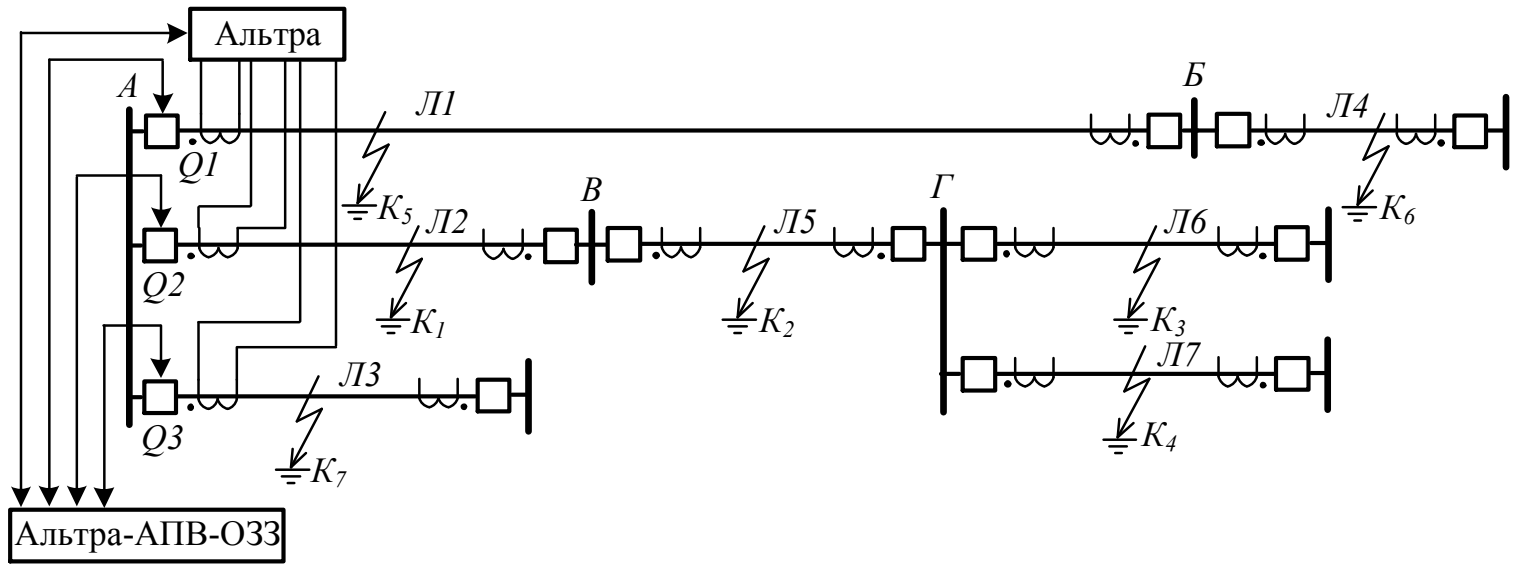

Рис. 3. Принџипова схема фізичної моделі електричної мережі

Як видно 3 рис. 3, в мережі використовується пристрій “Альтра”, який встановлений на підстанції $A$. Цей пристрій забезпечує селективне визначення лінії, на якій відбулося О33 та іiі вимкнення. На цій же підстанції встановлений пристрій, що забезпечує АПВ “Альтра-АПВ-ОЗ3”. Використовуючи особливості, які характерні для ОЗ3, розглядаємо схему електричної мережі лише для протікання струмів нульової послідовності. Для моделювання О3З на лініях мережі джерело напруги нульової послідовності необхідно вмикати у вибраному місці. В схемі фізичної моделі відсутні поздовжні параметри ліній активні та індуктивні опори, тому що вони $є$ набагато меншими від поперечних (ємнісних) опорів ліній.

На рис. 4 наведено схему управління комутаційним апаратом Q1 фізичної моделі електричної мережі. На схемі контакти $A 1.1, A 1.2, A 2.1$ - це вихідні контакти пристроїв захисту “Альтра" та “Альтра-АПВ-ОЗ3”. Реле Q1 моделює вимикач електричної мережі (це двообмоткове реле), $S B 1, S B 2$ - кнопки дистанційного ручного управління вимикачем. Аналогічно працюють схеми управління комутаційними апаратами $Q 2, Q 3$ фізичної моделі електричної мережі.

Створена фізична модель 3 достатньою точністю дозволяє моделювати процеси під час О3З в електричній мережі з ізольованою нейтраллю.

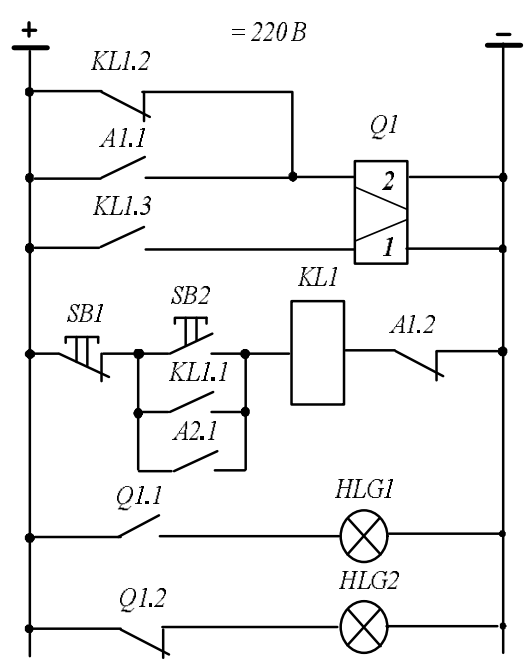

Рис. 4. Схема управління вимикачем фізичної моделі електричної мережі

\section{Висновки}

1. Розроблено алгоритм автоматичного повторного ввімкнення приєднання після вимкнення його захистом за однофазного замиканння на землю.

2. Розроблено мікропроцесорний пристрій “Альтра-АПВ-ОЗ3”, що реалізує функцію АПВ.

3. Створено фізичну модель електричної мережі з ізольованою нейтраллю, що дозволяє моделювати однофазні замикання на землю, роботу пристроїв релейного захисту та дію АПВ.

\section{Список використаних джерел}

1. Журахівський А. В. Ферорезонансні процеси та захист трансформаторів напруги в електричних мережах 6-35 кВ: монографія / А. В. Журахівський, 3. М. Бахор, О. І. Ганус, П. П. Говоров, А. Я. Яцейко. Львів: Видавниитво Львівської політехніки, 2019. 324 с. 
2. Захист електричних мереж 6-35 Кв від ферорезонансних процесів / А. В. Журахівський, Ю. А. Кенс, А. Я. Яцейко, Р. Я. Масляк. Технічна електродинаміка. 2013. № 5. С. 70-76.

3. Гловачкий В. Г., Пономарев И. В. Современные средства релейной защиты и автоматики электросетей. М.: Энергомашвин, 2003. 535 c.

4. Базилевич М. В., Божик Р. С., Сабадаш I. О. Мікропроцесорна інформаційно-діагностувальна система «Альтра» для селективного визначення приєднання з уземленою фазою. Енергетика та електрифікація. Київ, 2003. № 7. С. $9-95$.

5. Сабадаш I. О. Новітні мікропроцесорні технологї̈ в експлуатації мереж 6-35 кВ. Электрические сети и системы. 2011. № 6.

6. Кідиба В. П. Релейний захист електроенергетичних систем: навч. посібник. Львів: Видавництво Львівської політехніки, 2015. 504 с.

7. Голота А. Д. Автоматика в електроенергетичних системах: навч. посіб. К.: Вища шк., 2006.367 с.

8. Релейний захист. Цифрові пристрої релейного захисту, автоматики та управління електроенергетичних систем: навч. посіб. / О. С. Яндульський, О. О. Дмитренко; під загальною редакцією д.т.н. О.С. Яндульського. К.: НТУУ «КПІ», 2016. 102 с.

9. Баран П. М., Кідиба В. П., Шмагала В. М., Прииляк Я. Д. Спечіальне програмне забезпечення цифрової тестової системи для перевірки пристроїв релейного захисту та автоматики. Енергетика та електрифікачія. Київ, 2006. № 6. С. 25-32.

10. Баран П. М., Божик Р. С., Кідиба В. П., Лисяк Г. М., Сабадаш І. О., Проць Х. А. Фізична модель мережі з ізольованою нейтраллю для перевірки захистів від однофазних замикань на землю // Вісник Національного університету “Львівська політехніка”. Електроенергетичні та електромеханічні системи. 2011. № 707. C. 3-9.

\section{References}

1. Zhurahivskii A.V. Ferorezonansni protsesy ta zahyst transformatoriv napruhy $v$ elektrychykh merezhakh 6-35 KV: monohrafiia / A. V. Zhurahivskii, Z. M. Bakhor, O. I. Hanus, P. P. Hovorov, A. Ya. Yatseiko. Lviv: Vydavnytstvo Lvivskoi politekhniky, 2019. 324 p. (Ukr)

2. Zakhyst elektrychnykh merezh 6-35 kV vid ferorezonansnykh protsesiv / A. V. Zhurahivskii, Yu. A. Kens, A. Ya. Yatseiko, R. Ya. Masliak. Tekhnichna elektrodynamika, 2013. No 5. Pp. 70-76.

3. Glovatskiy V. G., Ponomarev I. V. Sovremennye sredstva zashchity i avtomatiki elektrosetey. Moskva: Energomashvin. 2003. 535 p. (Rus)

4. Bazylevych M. V., Bozhyk R. S., Sabadash I. O. Mikroprotsesorna informatsiino-diahnostuvalna systema “Altra” dlia selektyvnoho vyznachennia pryiednannia z uzemlenoiu fazoiu. Energetyka ta elektryfikatsiia. Kyiv, 2003. No 7. Pp. 91-95. (Ukr)

5. Sabadash I. O. Novitni mikroprotsesorni technolohii v ekspluatatsii merezh 6-35 kV. Elektricheskie seti $i$ sistemy. 2011. No 6. (Ukr)

6. Kidyba V. P. Releinyi zakhyst elektroenerhetychnykh system: navch. posibnyk. Lviv: Vydavnytstvo Lvivskoi politekhniky, 2015. 504 p. (Ukr)

7. Holota A. D. Avtomatyka v elektroenerhetychykh systemakh: navch. posibnyk. Kyiv: Vyshcha shkola, 2006. 367 p. (Ukr)

8. Releinyi zakhyst. Tsyfrovi prystroi releinoho zakhystu, avtomatyky ta upravlinnia elektroenerhetychykh system: navch. posibnyk / O. S. Yandulskyi, O. O. Dmytrenko; pid zahalnoiu redaktsiieiu O. S. Yandulskoho. Kyiv: NTUU “KPI”, 2016. 102 p. (Ukr)

9. Baran P. M., Kidyba V. P., Shmahala V. M., Pryshliak Ya. D. Spetsialne prohramne zabezpechennia tsyfrovoi testovoi systemy dlia perevirky prystroiv releinoho zakhystu ta avtomatyky. Energetyka ta elektryfikatsiia. Kyiv, 2006. No 6. Pp. 25-32. (Ukr)

10. Baran P. M., Bozhyk R. S., Kidyba V. P., Lysiak H. M., Sabadash I. O., Prots Kh. A. Fizychna model merezhi z izolovanoiu neitralliu dlia perevirky zakhystiv vid odnofaznykh zamykan na zemliu. Visnyk Natsionalnoho universytetu "Lvivska politekhnika". Elektroenerhetychni ta elektromekhanichni systemy. 2011. No. 707. Pp. 3-9. (Ukr) 
Lviv Polytechnic National University, Department of Electric Power Engineering and Control Systems, e-mail: petro.m.baran@1pnu.ua

\author{
V. Kidyba \\ Lviv Polytechnic National University, \\ Department of Electric Power Engineering and Control Systems, \\ e-mail:kidyba@ukr.net \\ Ya. Pryshliak \\ Lviv Polytechnic National University, \\ Department of Electric Power Engineering and Control Systems, \\ e-mail: pryshlak@gmail.com \\ I. Sabadash \\ Lviv Polytechnic National University, \\ Department of Electric Power Engineering and Control Systems, \\ e-mail: office@imskoe.org.ua
}

\title{
AUTOMATIC RECLOSING FOR ISOLATED NEUTRAL ELECTRIC GRID UNDER SINGLE-PHASE TO GROUND FAULT
}

(C) Baran P., Kidyba V., Pryshliak Ya., Sabadash I., 2020

6-35 kV electrical networks operates with isolated or compensated neutrals. Such mode of a neutral is the reason of emergence of considerable overvoltage in an electrical network during singlephase ground fault (SFGF), especially during short-circuit through an arc and various ferro-resonance phenomena. These overvoltage destroy the insulation of the electrically coupled network. Therefore, in order to increase the performance efficiency of the 6-35 $\mathrm{kV}$ network, it is necessary to minimize the operate time of overvoltage that are detrimental to the insulation of the network (especially cables). For this purpose it is necessary to use protections, which with minimum time delay disconnect feeder with SFGF. In order to reduce the time of de-energizing of consumers who have been disconnected by the protection during the SFGF, it is advisable to use automatic reclose (AR), which will lead to reduction of losses from electricity sacrifice. The AR automatically switches on an electic network element previously disconnected during the SFGF.

The algorithm of functioning of the APP is developed. On the basis of the developed algorithm with use of digital technologies the device by means of which it is possible to organize the APP function for a large number of connections to section of tires - up to 28 is manufactured.

To test the performance of the device created a physical model of the isolated neutral system, which allows to simulate SFGF. To protect against SFGF in the physical model used serial device "Altra", which is successfully operated at various power facilities in Ukraine - power, thermal power stations, substations of enterprises and more. The mutual operation of protection devices during SFGF and AR has been tested on a physical model. Various modes during SFGF in the electrical network (damage in different places of the electrical network) and different nature of SFGF (short-term with self-liquidation, stable without self-elimination) were simulated. The analysis of the results of the physical model verification confirmed the high efficiency of the integrated use of the protection devices during SFGF and AR in the isolated neutral system and compensated network. The device is currently being piloted at one of substations of "Lvivoblenergo".

Keywords: substation; relay protection; automatics; single-phase ground fault; avtomatic reclose; digital device; "Altra"; information network. 